erable antiquity, and the uppermost deposits unquestionably of modern date which alone can be invoked as evidence of recent subsidence. It would appear, also, that he has not clearly understood my paper; for it is otherwise difficult to account for such statements as "the hypothesis of a fluctuating high-tide level has no possible application" to the botanical evidence of present subsidence as presented by Dr. Davis; or that the hypothesis "has no bearing whatever on most of the evidence which has been offered." Surely if the height of ordinary high tides gradually rises one or more feet as the result of changes in the form of the shoreline without change in the level of the land, this increase in tidal height will produce all of the phenomena which would be produced by actual subsidence of the land, "now going on." The task which confronts the student of shoreline changes involves a discrimination between different causes producing like results; and the best method of making such a discrimination is, in the opinion of the writer, to deduce the character and magnitude of the results which each hypothetical cause is theoretically capable of producing under the varying conditions which exist along an irregular coast, and then to compare the deductions with the actual phenomena as observed in the field. So far as I have carried such an analysis for the Massachusetts coast, the evidences of supposed recent subsidence are all capable of interpretation on the basis of a fluctuating high tide surface; whereas physiographic features of much importance seem incompatible with the theory of continued recent subsidence.

D. W. Johnson

\section{MIASTOR AND EMBRYOLOGY}

Reproduction by insect larvæ, a form of parthenogenesis known as pedogenesis, is extremely interesting. The writer was fortunate last fall in finding, in the partially decayed chestnut bark of a rail fence, numerous Miastor larvæ, forms not previously recognized in this country, though several species and representatives of allied genera have been studied by a few Europeans. Miastor larvæ and their allies should be of great service to teachers of zoology and biology, since they admit of the study at first hand of this interesting phenomenon. It is possible, with a no more elaborate outfit than an ordinary student's microscope equipped with a threefourths objective, a microscopic slide and a few cover-glasses, to observe the vital activities of the young larva, to see the muscular, respiratory, digestive and nervous systems, to identify the ovaries and to watch the gradual development of the semi-transparent embryos within the body of the living mother larva. Furthermore, these forms are well adapted to more exact histological methods, being soft and therefore excellent subjects for serial sections and stains, particularly as it is comparatively easy to secure from one colony a series of individuals representing different stages of development.

Aside from the interest attached to their morphology and biology, there are other considerations which should appeal strongly to the teacher of zoology. These larvæ are widely distributed and, with an understanding of their habits, there should be little difficulty in finding them. They are small, and a piece of wood six inches long, three inches wide and half an inch thick, may contain or produce enough material for a fair-sized section or class. The larvæ are prolific and, under favorable conditions, would probably multiply at any season of the year. This is certainly true of the fall, the early winter and the spring. They can be kept alive for at least a month in microscopic cells, and with care a larval generation will develop in such restricted quarters. We have kept larvæ healthy and multiplying for nearly three months with nothing more elaborate than a moist piece of decaying wood clamped lightly to an ordinary microscopic slide and kept in a moist, dark box. Many of the larvæ were content with conditions on the surface of the wood, next the glass, and were therefore easily observed. These remarkable larvæ are very hardy; prolonged dryness simply results in a suspension of activities, while they are quite resistant to an abundance of moisture. Embryos will continue their development in mother larvæ even 
though the latter be kept for weeks in a sealed cell filled with water. It is even possible to make very satisfactory photomicrographs of living embryos within the mother larvæ, while there is not the slightest difficulty in observing the movements of those nearly fully developed before their escape from the mother integument. With our present knowledge we see no reason why artificial colonies of this insect might not be established in the vicinity of a zoological laboratory and maintained with very little or no attention from year to year, if not for a decade or more. A detailed account of this species, with a number of illustrations will appear shortly in the writer's report for last year.

E. P. FeLt

TREMATODES OF THE DRY TORTUGAS

My friend Albert Hassall has called my attention to two of the new generic names which I employed in a recent paper on the Trematodes of the Dry Tortugas. ${ }^{1}$

The generic names Didymorchis and Mesorchis are preempted, thus making it necessary to invent other names to take their place. I therefore propose for Didymorchis the name

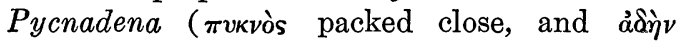
a gland), and for Mesorchis the name Antorchis (åviios opposite, and ö $\rho$ ¿५s).

These two specific names hence become Pycnadena (n. g.) lata (Lt.) and Antorchis (n. g.) urna (Lt.).

At the suggestion of Mr. Hassall I take advantage of this opportunity to state that Deradena ovalis, Hamacreadium mutabile and Genolopa ampullacea are the type species of their respective genera.

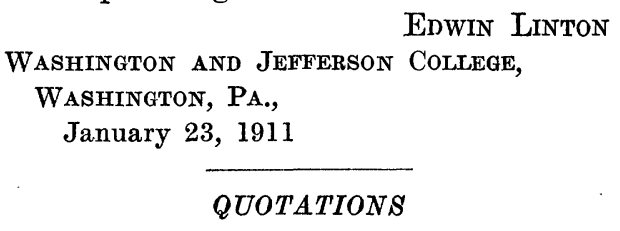

\section{COMMERCIALISM IN EDUCATION}

That the methods of higher education are in a state of transition in this country ap-

1 "Helminth Fauna of the Dry Tortugas, II., Trematodes," Papers of the Tortugas Laboratory, Carnegie Institution of Washington, Vol. IV., pp. 11-98, plates 1-28; issued December 16, 1910. pears evident from the pedagogic innovations made and the many more proposed during the past several years. On the one hand, colleges of higher standing are elevating their curricula to a real professional plane, apparently having at length found it too difficult, to say the least, to instruct in the same course men for such different callings as dynamo tender and consulting engineer. On the other hand, some schools are frankly revealing that their aim is to serve, not the interests of the student, but solely those of the employer of technical graduates, even though education directed primarily to this narrow purpose may unfit the subject for obtaining the most out of life spiritually, through lowering his ideals and curbing his ambitions, and financially, through making him a mere serf to an industry. A concrete illustration of the haphazard condition of thought concerning technical education is afforded by a recent report of the Carnegie Foundation for the Advancement of Teaching on "Academic and Industrial Efficiency," prepared by a well-known and doubtless capable "efficiency engineer," whose business is concerned with the economical administration of manufacturing establishments.

While we have no quarrel with the efficiency engineer as such, nor with his efforts in the course of business to report upon any problem which his clients may desire investigated, we can not refrain from expressing astonishment at the frame of mind of one who would direct the application to instruction in science of the canons appropriate for running a purely money-making business. The possibility of such a distortion of view is the most serious criticism that could possibly be launched against American educational methods. As well put a skilful and successful sausage maker at the task of criticizing the manufacture of astronomical telescopes. An institution for training young men in science, whether pure or applied, is not a money-getting concern. Its product is not sausages, but the advancement of human intelligence, which may or may not be applied to gainful objects. Even in the narrowest technical sense it does 